\title{
Evaluation of Antipyretic and Analgesic Effects of Alchornea cordifolia Schum. \& Thonn. (Euphorbiaceae) and Quassia africana Baill (Simaroubaceae)
}

\author{
Nsonde Ntandou G. F. ${ }^{1,2}$, Kimpouni $V_{0}{ }^{3}$, \\ Dianzitoukoulou Matsima L. D. ${ }^{2,4}$, Abena A. A. ${ }^{1}$
}

${ }^{1}$ Laboratoire de biochimie et pharmacologie, Faculté des Sciences de la Santé, Université Marien Ngouabi, BP 69, Brazzaville, Congo

${ }^{2}$ Laboratoire de Physiologie et Physiopathologie Animales, Faculté des Sciences et Techniques, Université Marien NGOUABI, Brazzaville, BP 69, Congo

${ }^{3}$ Ecole Normale Supérieur, Université Marien NGOUABI, Brazzaville, BP 237, Congo

${ }^{4}$ Unité de Chimie du végétal et de la vie, Faculté des Sciences et Techniques, Université Marien Ngouabi, BP 69, Brazzaville, Congo

\begin{abstract}
Alchornea cordifolia (Euphorbiaceae) is widely used in Africa for the treatment of malaria, fever, tooth decay, leprosy, amoebic dysentery, hemorrhoids, headaches, venereal diseases and inflammation. It is also used as emmenagogue and oxytocic. Quassia africana (Simaroubaceae) is also widely used in Africa for the treatment of malaria, gastritis, intestinal worms, rheumatism, bronchopneumonia, gonorrhea, headache, tooth decay and tonsillitis. The present study aims to highlight the analgesic and antipyretic effects of both plants. Fever was induced by oral administration of $20 \mathrm{ml} / \mathrm{kg}$ of $20 \%$ beer yeast in rats 24 hours before treatment. The rectal temperature was measured $1 \mathrm{~h}, 2 \mathrm{~h}$ and $3 \mathrm{~h}$ after treatment. The pain was induced by intraperitoneal injection of $0.1 \mathrm{ml} / 10 \mathrm{~g}$ of $0.6 \%$ acetic acid in rats 1 hour after oral treatment. The analgesic activity was assessed for 10 minutes by counting the number of cramps. The aqueous, ethanolic and dichloromethane extracts of the leaves and fruits of Alchornea cordifolia at 400 and $800 \mathrm{mg} / \mathrm{kg}$ per os showed a very significant antipyretic effect identical to paracetamol at 100 $\mathrm{mg} / \mathrm{kg}$ per os. The aqueous extracts of the leaves and fruits of Alchornea cordifolia as well as barks of Quassia africana at 400 and $800 \mathrm{mg} / \mathrm{kg}$ per os showed a very significant analgesic effect. These effects are related to the presence of alkaloids and terpenes for Alchornea cordifolia and Quassinoides for Quassia africana.
\end{abstract}

Keywords: Alchornea Cordifolia, Quassia Africana, Extracts, Analgesic, Antipyretic

Résumé: Alchornea cordifolia (Euphorbiaceae) est très utilisée en Afrique dans les traitements du paludisme, de la fièvre, de la carie dentaire, de la lèpre, de la dysenterie amibienne, des hémorroïdes, des céphalées, des maladies vénériennes et de l'inflammation. Elle est aussi utilisée comme emménagogue et ocytocique. Quassia africana (Simaroubaceae) est aussi une espèce largement utilisée en Afrique dans le traitement du paludisme, de la gastrite, des vers intestinaux, de rhumatisme, de la bronchopneumonie, de la blennorragie, des céphalées, de la carie dentaire et des angines. La présente étude vise à mettre en évidence des effets antalgique et antipyrétique de ses deux plantes. La fièvre a été induite par administration orale de $20 \mathrm{ml} / \mathrm{kg}$ de levure de bière à $20 \%$ chez le rat, $24 \mathrm{~h}$ avant le traitement. La température rectale a été mesurée $1 \mathrm{~h}, 2 \mathrm{~h}$ et $3 \mathrm{~h}$ après traitement. La douleur a été induite par injection de $0,1 \mathrm{ml} / 10 \mathrm{~g}$ de l'acide acétique à $0,6 \%$ par voie IP chez le rat $1 \mathrm{~h}$ après traitement oral. L'activité antalgique a été appréciée pendant 10 minutes en comptant le nombre de crampes. Les extraits aqueux, éthanolique et au dichloromethane des feuilles et des fruits de Alchornea cordifolia à 400 et $800 \mathrm{mg} / \mathrm{kg}$ per os ont montré un effet antipyrétique très significatif et comparable au paracétamol à $100 \mathrm{mg} / \mathrm{kg}$ per os. Les extraits aqueux des feuilles et des fruits de Alchornea cordifolia ainsi que des écorces de Quassia africana à 400 et $800 \mathrm{mg} / \mathrm{kg}$ per os ont montré un effet antalgique très significatif. Ces effets seraient liés à la présence des alcaloïdes et des terpènes pour Alchornea cordifolia et aux quassinoides pour Quassia africana.

Motsclés: Alchornea cordifolia, Quassia africana, Extracts, Antalgique, Antipyrétique

This article is published under the terms of the Creative Commons Attribution License 4.0 Author(s) retain the copyright of this article. Publication rights with Alkhaer Publications. Published at: http://www.ijsciences.com/pub/issue/2020-01/

DOI: 10.18483/ijSci.2255; Online ISSN: 2305-3925; Print ISSN: 2410-4477 


\section{Introduction}

Leaves, barks, roots and fruits of Alchornea cordifolia (Euphorbiaceae) are widely used in traditional medicine. This plant is used in Africa in several treatments: malaria, fever, tooth decay, leprosy, amoebic dysentery, hemorrhoids, personal hygiene, headaches, venereal diseases and inflammation (OMS, 1978; Bouquet, 1969; Adjanohoun et al., 1994). Pharmacologically, Alchornea cordifolia is known for its effects against malaria, trypanosomiasis ( Mesia et al., 2008), bacterial and fungal infections (Gatsing et al., 2010; Mambe et al., 2016; Akpo et al., 2016; Noundou et al., 2016; Ebenyi et al., 2017), inflammation (MavarManga et al., 2008; Adejuwon et al., 2014), antioxidant activity (Olaleye et al., 2007,), diarrhoeal (Agbor et al., 2004; Emudainohwo et al., 2015), nervous system (Umukoro et al., 2010; Kamenan et al., 2013; Ishola et al., 2014), diabetic (Mohammed et al., 2012; Thomford et al., 2015), HIV-1 (Noundou et al., 2019), hepatotoxicity . Phytochemical investigations revealed flavonoids, tannins, saponins, glycosides, terpenoids, carbohydrate and imidazopyrimidine alkaloids, alchorneine, alchornidine and several guanidine alkaloids as chemical groups present in all parts. As molecules, leaves contain a range of hydroxybenzoic acid, namely, gallic acid, anthralinic acid, protocatechuic acid and ellagic acid, stigmasterol, stigmasta - 4, 22dien-3-one, friedelin, friedelane, 3-O-acetylaleuritolic acid, 3- O-acetyl-erythrodiol and methyl-3, 4, 5- trihydroxybenzoate (methyl gallate); the seed oil contains alchornoic (Ngaha et al., 2016; Noundou et al., 2016).

Quassia africana (Simaroubaceae) is also widely used in Africa for the treatment of malaria, gastritis, intestinal worms, rheumatism, bronchopneumonia, gonorrhea, headache, tooth decay and angina (Adjanohoun et al., 1988; Bouquet, 1969). Pharmacologically, antimalarial (Kirby et al., 1989; Mbatchi et al., 2006), amoebicide (Wright et al., 1988), pediculosis (Jensen et al., 1978), insecticid, antiviral (Apers et al., 2002; Diehl et al., 2016), antinflammatory (Toma et al.,2003; Guo et al., 2005), antitumor, anti-ulcer (Toma et al., 2002; Yinsua et $a l ., 2012$ ), antifertility properties have been notified in Quassia genus. In the Simaroubaceae family, numerous compounds have been isolated and their structure has been elucidated; among these, quassinoids, alkaloids, triterpenes, steroids, coumarins, anthraquinones, and flavonoids and other metabolites (Barbosa et al., 2011). The present study aims to evaluate the analgesic and antipyretic effects of thise plants.

\section{Material and methods}

\section{Animal material}

Wistar rats, both sexes, weighing between 150 and $200 \mathrm{~g}$ were used. Animals are raised in the animaleria of Laboratoire de Physiologie et Physiopathologie animales of the Faculty of Science and Technology
(FST) under standard conditions $\left(25 \pm 5^{\circ} \mathrm{C}, 40-70\right.$ $\mathrm{HR}$, cycle light / dark $12 \mathrm{~h}$ ), they were regularly fed and had free access to water. The ethical rules of animal experiments published by the International Association for the Study of Pain was respected (Canadian Council 1980; Zimmermann, 1983).

\section{Plants material}

The roots and leaves of Quassia Africana, and leaves and fruits of Alchornea cordifolia collected at Makana village in the Department of the Pool-Congo, were used. These samples were identified in the Congo National Herbarium by botanists from the Botany Laboratory of the Institut National de Recherche en Sciences de la Santé (IRSSEN) of Brazzaville-Congo. A specimen voucher from each sample was deposited and registered under the number QAS003 (Quassia africana) and ACE005 (Alchornea cordifolia).

\section{Preparations of plants extracts}

We made a decoction in water and macerations with ethanol and dichloromethane. The decoction was prepared by boiling $25 \mathrm{~g}$ of plant material in $250 \mathrm{ml}$ of water at $100^{\circ} \mathrm{C}$ for $30 \mathrm{~min}$. The macerate was prepared by placing $25 \mathrm{~g}$ of plant material (leaves and fruit) in $250 \mathrm{ml}$ of organic solvents (ethanol or dichloromethane). The mixture was stirred for $24 \mathrm{~h}$, before being filtered successively with a cotton wool and a filter paper (wattman). The filtrates were concentrated. For experimentation, organic extracts were dissolved in $10 \%$ of Tween 80 .

\section{Treatments of rats}

Rats of the same age, were divided into seven (7) lots of 5 rats each and fasted 24 hours before the experiment. These rats were orally treated as follows:

\subsection{Treatment of antipyretic effect evaluation}

- Lot 1 received the distilled water at a dose of $1 \mathrm{ml} /$ $100 \mathrm{~g}$ of rat body weight;

- Lot 1' received the Tween $80(10 \%)$ at a dose of $1 \mathrm{ml} / 100 \mathrm{~g}$ of rat body weight;

- Lot 2 received the paracetamol at a dose of $100 \mathrm{mg} /$ $\mathrm{kg}$ of rat body weight;

- Lot 3 received the aqueous leaf extract of Alchornea cordifolia at a dose of $400 \mathrm{mg} / \mathrm{kg}$ of rat body weight;

Lot 4 received the aqueous extract of leaves of Alchornea cordifolia at a dose of $800 \mathrm{mg} / \mathrm{kg}$ of rat body weight;

- Lot 5 received the aqueous extract of the fruit of Alchornea cordifolia at the dose of $400 \mathrm{mg} / \mathrm{kg}$ of rat body weight;

- Lot 6 received the aqueous extract of the fruit of Alchornea cordifolia at a dose of $800 \mathrm{mg} / \mathrm{kg}$ of rat body weight;

- Lot 7 received the aqueous root extract of Quassia africana at a dose of $800 \mathrm{mg} / \mathrm{kg}$ of rat body weight; - Lot 8 received the aqueous root extract of Quassia africana at a dose of $400 \mathrm{mg} / \mathrm{kg}$ of rat body weight; 
- Lot 9 received the ethanolic extract of leaves of Alchornea cordifolia at a dose of $400 \mathrm{mg} / \mathrm{kg}$ of rat body weight;

- Lot 10 received the dichloromethane extract from leaves of Alchornea cordifolia at a dose of $400 \mathrm{mg} /$ $\mathrm{kg}$ of rat body weight;

- Lot 11 received the ethanolic extract of the fruit of Alchornea cordifolia at a dose of $400 \mathrm{mg} / \mathrm{kg}$ of rat body weight;

- Lot 12 received the dichloromethane extract from the fruit of Alchornea cordifolia at a dose of $400 \mathrm{mg} /$ $\mathrm{kg}$ of rat body weight.

\subsection{Treatment of analgesic effect evaluation}

- Lot 1 received distilled water at a dose of $1 \mathrm{ml} /$ $100 \mathrm{~g}$ of rat body weight;

- Lot 2 received paracetamol at a dose of $100 \mathrm{mg} / \mathrm{kg}$ of rat body weight;

- Lot 3 received the aqueous leaf extract of Alchornea cordifolia at a dose of $400 \mathrm{mg} / \mathrm{kg}$ of rat body weight;

- Lot 4 received the aqueous extract of leaves of Alchornea cordifolia at a dose of $800 \mathrm{mg} / \mathrm{kg}$ of rat body weight;

- Lot 5 received the aqueous extract of the fruit of Alchornea cordifolia at the dose of $400 \mathrm{mg} / \mathrm{kg}$ of rat body weight;

- Lot 6 received the aqueous extract of the fruit of Alchornea cordifolia at a dose of $800 \mathrm{mg} / \mathrm{kg}$ of rat body weight;

- Lot 7 received the aqueous root extract of Quassia africana at a dose of $800 \mathrm{mg} / \mathrm{kg}$ of rat body weight;

- Lot 8 received the aqueous root extract of Quassia africana at a dose of $400 \mathrm{mg} / \mathrm{kg}$ of rat body weight.

\section{Evaluation of the antipyretic effect}

To each animal fasting for 24 hours, the rectal temperature is measured and orally $20 \mathrm{ml} / \mathrm{kg}$ of $20 \%$ yeast beer is administered (Nsonde Ntandou et al., 2016) $24 \mathrm{~h}$ later, a new rectal temperature is measured (T24h). Animals showing a rise in rectal temperature $\geq 0.5^{\circ} \mathrm{C}$ were selected for study and then treated. After administration of the products, the rectal temperature was further measured after one (1) hour, two (2) hours, and three (3) hours.

\section{Evaluation of the analgesic effect}

One hour after administration of the test products, each rat is treated with $0.1 \mathrm{ml} / 10 \mathrm{~g}$ of $0.6 \%$ acetic acid IP and placed in a cage (Nsonde Ntandou et al., 2018). The analgesic activity is appreciated for 10 minutes by counting the number of cramps (stretching of the legs and dorso-abdominal torsion of the muscles). The result was expressed as percent inhibition calculated according to the formula:

$\%$ inhibition $=100$ (Number of cramps in the control group-number of cramps in the treated batch) / Average cramps

\section{Statistical analyzes}

The results are expressed on average \pm SD for a number of $n=5$ rats per lot using the Microsoft Excel Windows 7 software. The results obtained in the test groups were compared to the control lot using the Student's t test. Significances were established at $* \mathrm{p}$ $<0.5, * * \mathrm{p}<0.01$ and $* * * \mathrm{p}<0.001$.

\section{Results}

\section{Antipyretic effect}

1.1. Antipyretic effect in rats treated with aqueous extracts of both plants

The administration of $20 \%$ brewer's yeast caused an increase in the rectal temperature of $1.2 \pm 0.05$ of the lots of the rats used in the antipyretic effect evaluation. The figure 1 shows the effect of Alchornea cordifolia aqueous extracts of leaves and fruits, Quassia africana roots at the doses 400 and $800 \mathrm{mg} / \mathrm{kg}$, distilled water $(10 \mathrm{ml} / \mathrm{kg})$, and paracetamol $(100 \mathrm{mg} / \mathrm{kg})$ on the yeast induced hyperthermia following oral administration. It shows that the 400 and $800 \mathrm{mg} / \mathrm{kg}$ of Alchornea cordifolia aqueous extracts of leaves and fruits as well as the reference drug significantly $(\mathrm{p}<0.01)$ lowered the rectal body temperature. 
Evaluation of Antipyretic and Analgesic Effects of Alchornea cordifolia Schum. \& Thonn. (Euphorbiaceae) and Quassia africana Baill (Simaroubaceae)

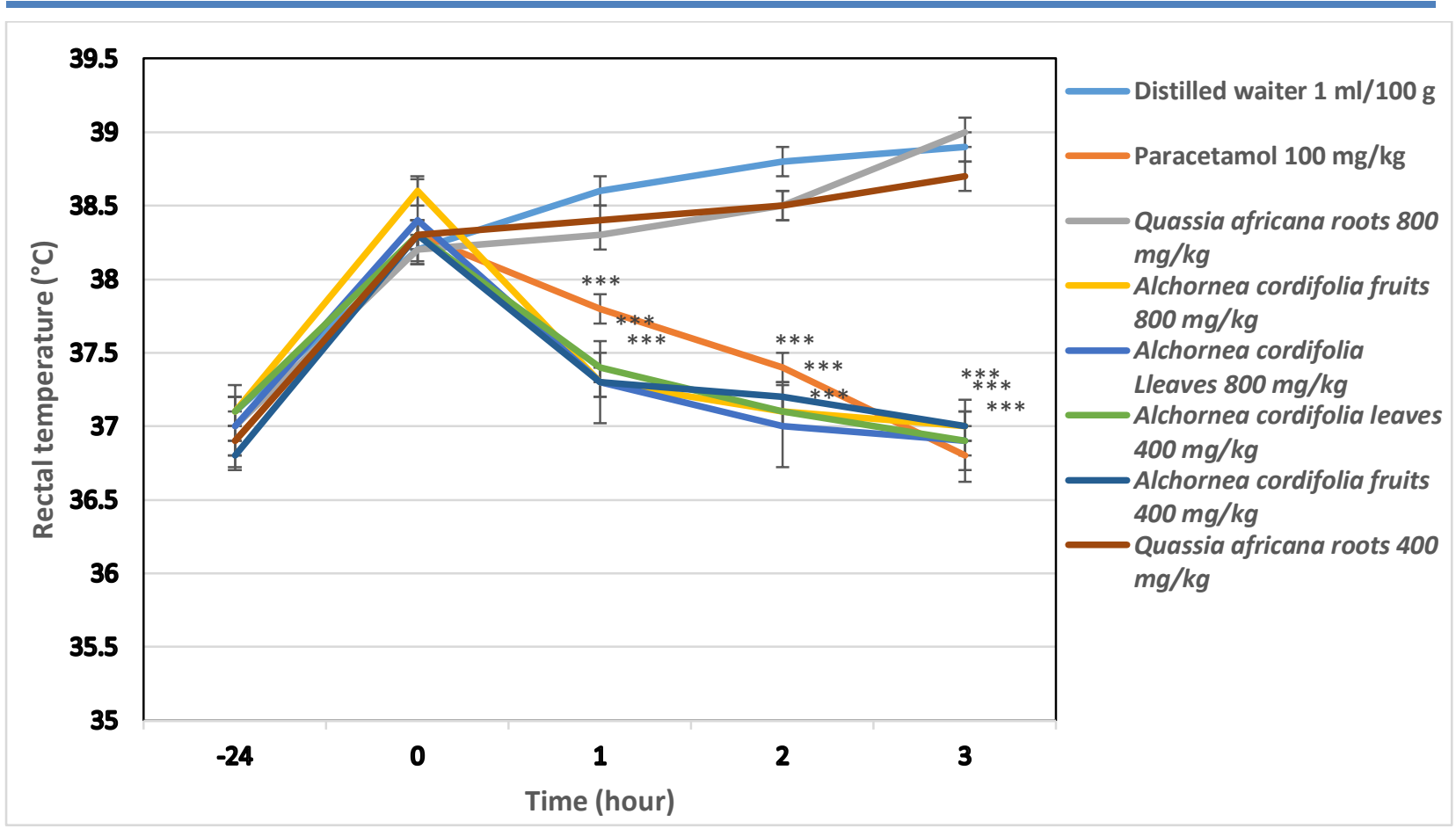

Figure 1. Effect of aqueous extracts of leaves and fruits of Alchornea cordifolia and roots of Quassia africana on the hyperthermia induced by brewer's yeast, results expressed as mean $\pm \mathrm{SD}, \mathrm{n}=5$, *** $\mathrm{p}<0.001$ compared to controls.

\subsection{Antipyretic effect in rats treated with ethanol and dichloromethane extracts of Alchornea cordifolia}

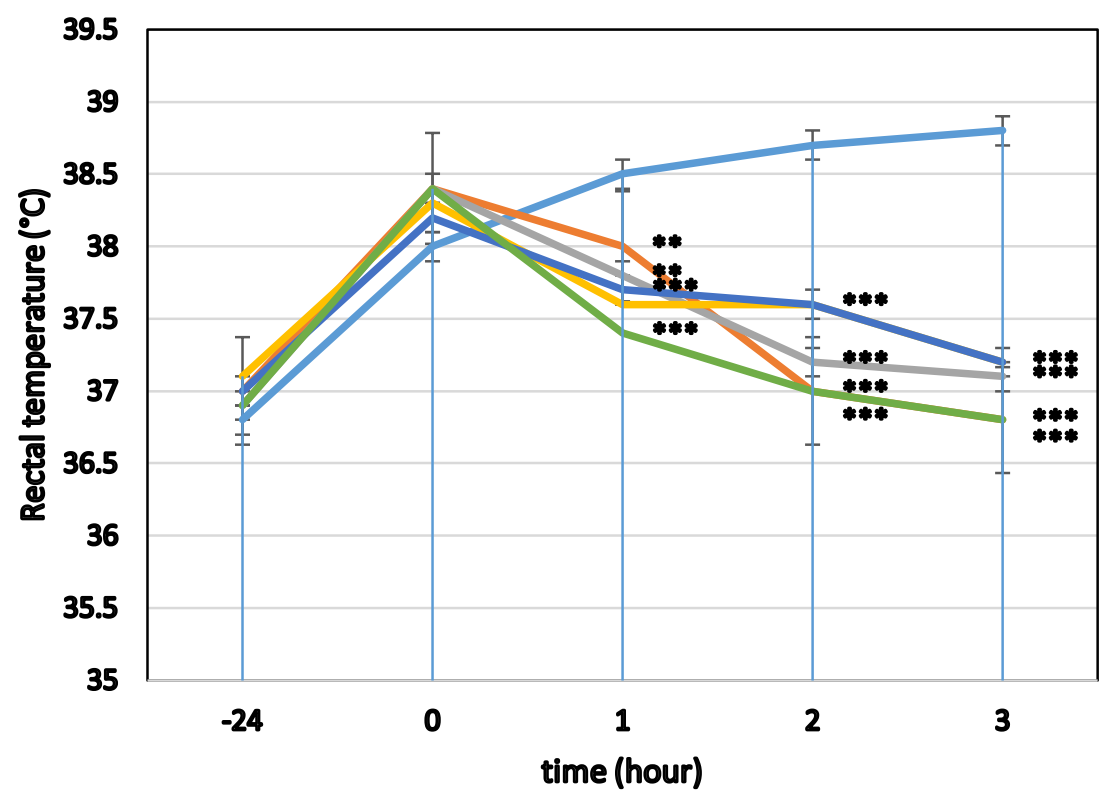
Tween $80(10 \%) 1$
$\mathrm{ml} / 100_{\mathrm{g}}$

Paracetamol $100 \mathrm{mg} / \mathrm{kg}$

Alchornea cordifolia leaves in ethanol $\mathbf{4 0 0}$ $\mathrm{mg} / \mathrm{kg}$ Alchornea cordifolia fruits in ethanol $\mathbf{4 0 0}$ $\mathrm{mg} / \mathrm{kg}$ Alchornea cordifolia fruits in DCM 400 $\mathrm{mg} / \mathrm{kg}$

Figure 2. Effect of the ethanolic and dichloromethane extracts of leaves and fruits of Alchornea cordifolia at the dose of $400 \mathrm{mg} / \mathrm{kg}$, following hyperthermia induced by brewer's yeast, results expressed on average \pm DS, $\mathrm{n}=5$, $* * * \mathrm{p}<0.001$ compared to the control. 
Evaluation of Antipyretic and Analgesic Effects of Alchornea cordifolia Schum. \& Thonn. (Euphorbiaceae) and Quassia africana Baill (Simaroubaceae)

\section{Analgesic effect}

Figures 3 and 4 show the effect of products on the acetic acid abdominal cramps. The rats received distilled water, the number of contortions is significantly very pronounced compared with those which were treated with paracetamol at $100 \mathrm{mg} / \mathrm{kg}$ and the different aqueous extracts at the doses of 400 and $800 \mathrm{mg} / \mathrm{kg}$.

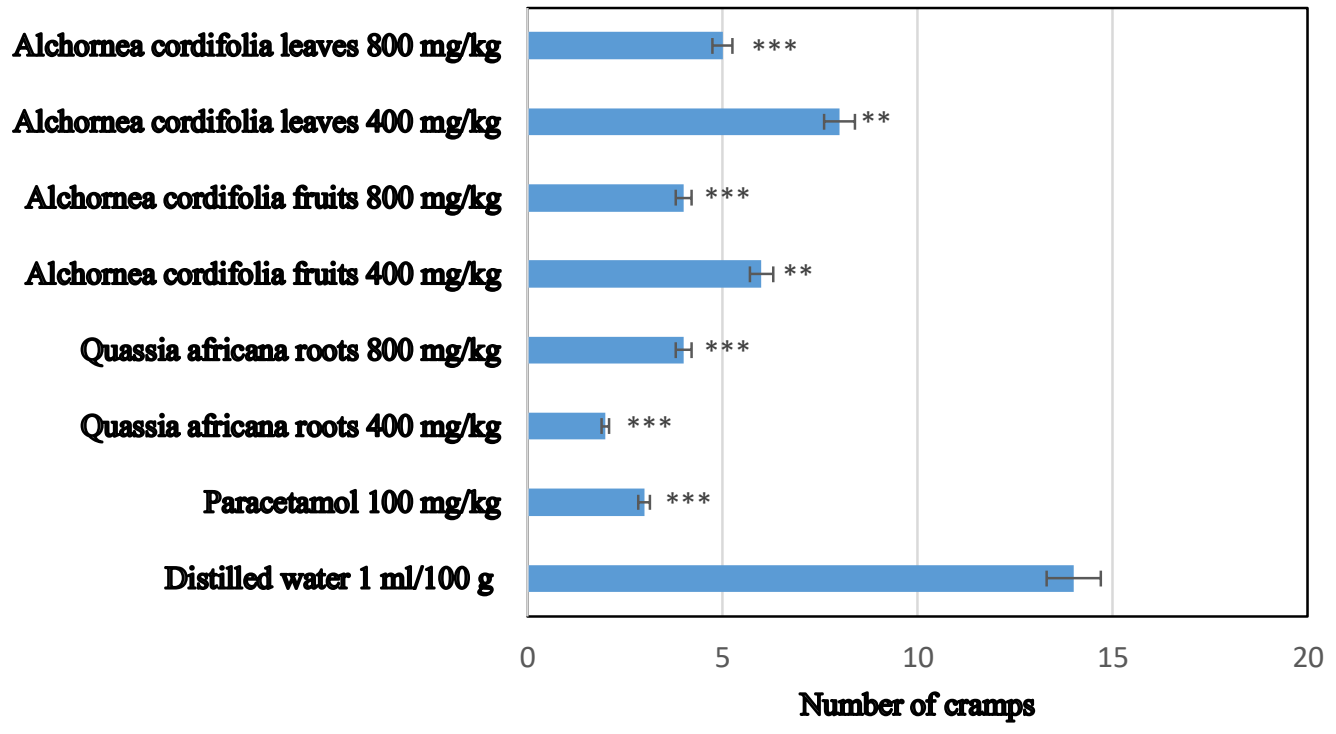

Figure 3. Effect of Quassia africana roots and Alchornea cordifolia fruits and leaves aqueous on abdominal cramps induced by acid acetic $n=5$,

$* * p<0.01,{ }^{* * *} p<0.001$ significant difference compared to control.

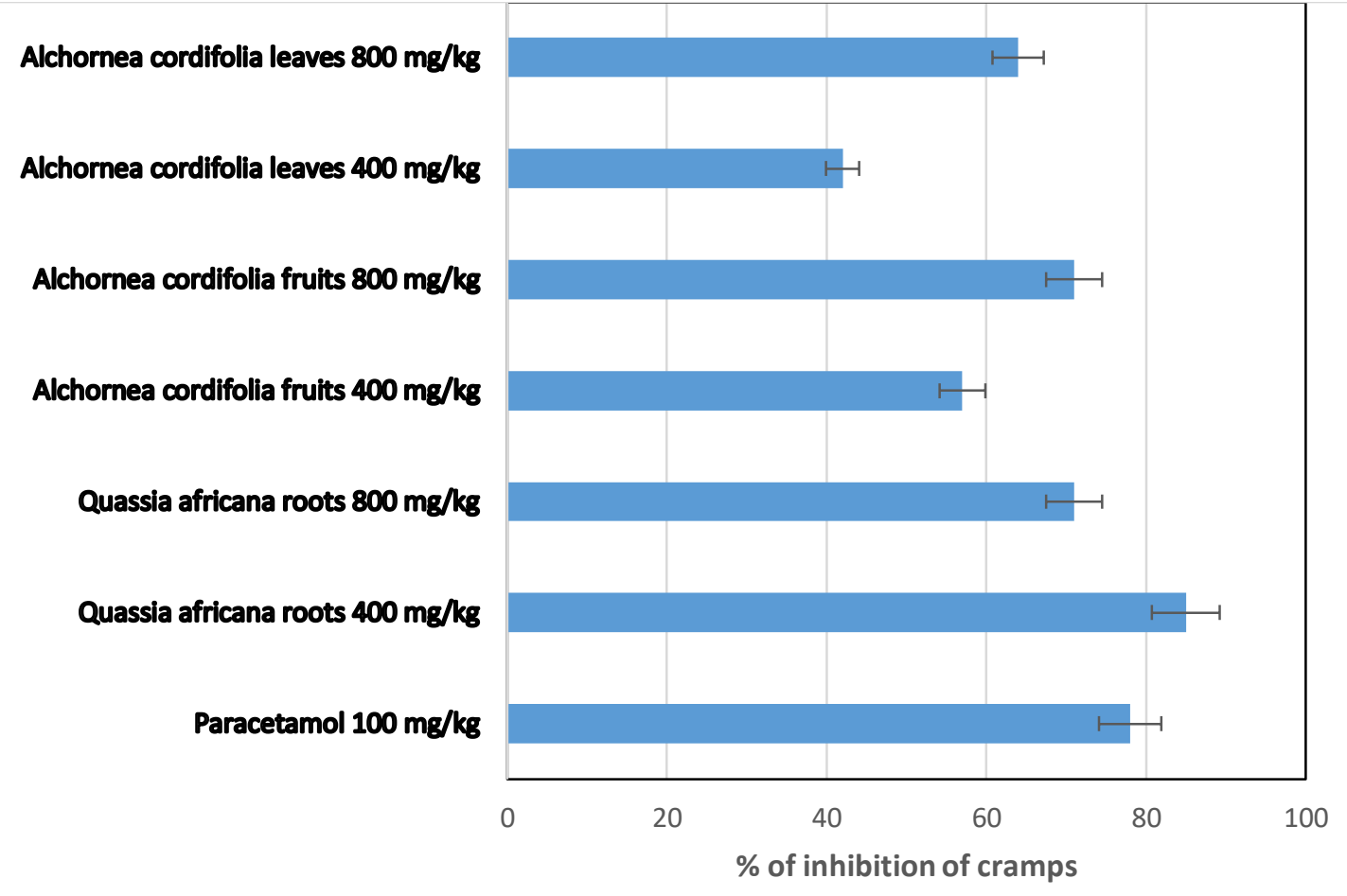

Figure 4. \% inhibitions of abdominal cramps induced by acid acetic of Quassia africana roots and Alchornea cordifolia fruits and leaves aqueous extracts $n=5$ 


\section{Discussion}

Fever is a result of the secondary impact of infection, tissue damage, inflammation, graft rejection, malignancy or other diseased. Brewer's yeast is commonly used to induce pyrexia in rats (Nsonde Ntandou et al., 2016). Brewer's yeast induces pyrexia by increasing the synthesis of prostaglandins (PGE2). From the work carried out in the rats, we could demonstrate the antipyretic effect of plants extracts. However, these plants have interesting pharmacological properties and have been studied in order to confirm or deny the therapeutic virtues cited by traditional healers in Congo. Alchornea cordifolia has good pharmacological activities and is not toxic. In this work, aqueous and organic leaves and fruits extracts of Alchornea cordifolia have presented more good results. Alchornea cordifolia extracts at different doses has significant antipyretic effects. The effect at the dose of $400 \mathrm{mg} / \mathrm{kg}$ is equal to that of paracetamol. However, Effo et al. (2013) have already shown antipyretic effect of Alchornea cordifolia methanol leaves extract with Ivory Coast sample (Okokon et $a l, 2017$ ); our study confirms this antipyrectic effect with congolese sample and have particularity to demonstrated this effect using water, ethanol and DCM extract and using fruits as other organ samples.

These results confirm the traditional use of Alchornea cordifolia as antipyretic. This effect is due to the presence of alkaloids, terpenes since these chemical families possess antipyretic properties.

From the work done in rats, we could check the analgesic effect of plants extracts. IP injection of $0.6 \%$ acetic acid in rats caused a painful effect which was manifested by stretching movements of the hind legs and the dorso-ventral musculature. These cramps which occur after injection of acetic acid are produced by prostaglandin PGE2 and PGF alpha synthesized in the presence of cyclooxygenase-2. Plants extracts expressed their antalgic power by inhibiting the synthesis of prostaglandins. The disadvantage with the chemical method is that the pain can be induced by the injury caused by the needle. Quassia Africana and Alchornea coordifolia extracts, and paracetamol significantly reduce abdominal cramps caused by injection of acetic acid to $0.6 \%$. This reduction of cramps number reveals significant analgesic activity mediated peripherally. Both plants have antalgic effect. However, at a dose of $400 \mathrm{mg} / \mathrm{kg}$, roots extract of Quassia Africana has most interesting antalgic effect than Alchornea cordifolia extracts (400 and $800 \mathrm{mg} / \mathrm{kg})$ and paracetamol $(100 \mathrm{mg} / \mathrm{kg})$. The extract from Quassia africana shows that it is more significant at the dose of $400 \mathrm{mg} / \mathrm{kg}$ than at the dose of $800 \mathrm{mg} / \mathrm{kg}$. This effect is similar with those found with Quassia amara another simaroubaceae (Toma et al., 2003). In our study we exhibited the antalgic effect of Alchorean codifolia in leaves and fruits extracts. This finding is in accordance with Ismaila et al. (2010) which demonstrated antinociceptif activity of the aqueous root extract of Alchornea cordifolia. In species of Simaroubaceae and Euphorbiaceae families it was demonstrated anti-inflammatory effect (Adejuwon et $a l, 2014$; Mavar-Manga et al., 2018). We know that antinflammatory drugs are for the most part analgesic. The pharmacological effect of Quassia africana is related to the presence of quassinoids (Wright et al., 1988; Apers et al., 2002; Alvesa et al., 2014; Guo et al., 2005).

\section{References}

1. Adejuw on A. A., Adekunle I. O., Ismail O. I., Hassanat A. K. Evaluation of the anti-arthritic activity of the hydroethanolic leaf extract of alchornea cordifolia in rats, Afr. J. Tra, Comple and Alter. Med. 2014, 11: 402-410.

2. Adjanohoun E. J., Aké Assi L., Taffam K. K., Keoula Y., Kluga-Ocloo W.P. Contribution aux études ethnobotaniques et floristiques en République Populaire du Congo. ACCT, Paris, 1988: 605 p.

3. Adjanohoun E., Cuset G., Issa Lo, Keita A., Le Bras M. \&Lejoly J., , Banque des données de médecine traditionnelle et pharmacopée (PHARMEL). Notice pour la collecte et l'entrée des données, seconde édition P.U.B, Bruxelles, 1994 : 142 p.

4. Alvesa I. A.B.S., Miranda H. M., Soaresa L. A.L., Randaua K. P.,. Simaroubaceae family: botany, chemical composition and biological activities. Rev. Bras. Farmacogn. 2014, 24: 481-501.

5. Akpo, C. O. and Owhe-Ureghe, U. B.. Alchornea cordifolia: a herb with the potential for phytotherapy against clostridium tetani, pseudomonas aeruginosa and staphylococcus aureus. Nigerian Journal of Science and Environment, 2016, 14 (1):77-84.

6. Apers S., Cimanga K., Van den Bergehe D., Van Meenen W., Longanga A.O., Foriers A., Vlietinck A., Pieters L.,. Antiviral activity of simalikalactone D, a quassinoids from Quassia Africana. Planta Med. 2002, 68(1): 20-24.

7. Agbor G.A., Leopold T., Jeanne N.Y., 2004. The antidiarrhoeal activity of Alchornea cordifolia leaf extract. Phytotherapy Research 18: 873-876.

8. Barbosa L., Braz-Filho R., Vieira I.. Chemical constituents of plants from the genus Simaba (Simaroubaceae). Chem. Biodivers, $8: 2163-2178$.

9. Bouquet A, 1969-Féticheurs et Médecine Traditionnelle du Congo Brazzaville, Mémoire ORSTOM, N³6, Brazzaville, $2011: 249 p$.

10. Bouquet A- Plantes médicinales du Congo-Brazzaville, Mémoire ORSTOM, N³6, Brazzaville, 1972 : 116p.

11. Bouquet et Jacquot A- Essai de géographie linguistique sur quelques plantes médicinales du Congo Brazzaville, 1967 : 32p.

12. Canadian council on Animal care. Guide to the Care use of experimental animals. Vol 1, appendix IV, 1980: 85p.

13. Diehl C., Reznichenko N., Casero R., Faenza L., Cuffini C., Palacios S.. Novel antibacterial, antifungal and antiparasitic activities of Quassia amara wood extract. International Journal of Pharmacology, Phytochemistry and Ethnomedicine, ,2016:2: 62-71.

14. Ebenyi L. N., Nwakaeze A. E.,Moses I. B., Iroha I. R., Uzoeto J.O., Ugochukwu J. I., Eddison I. O. and Okamkpa C. J. Antibacterial activity of Alchornea cordifolia leaves found in Ebonyi state, Nigeria. International Journal of Advances in Pharmacy, Biology and Chemistry IJAPBC, 2017; 6(1):4651.

15. Effo K. E., Kouakou-Siransy G., Irie-Nguessan G., Sawadogo R. W., Dally I. L., Kamenan A. B., Kouakou L. S., Kablan-Brou J. Acute toxicity and antipyretic activities of a methanolic extract of Alchornea cordifolia leaves. Pharmacology \& Pharmacy, 2013; 4: 1-6.

16. Emudainohwo J.O.T., Goodies E. M., Daniel E.E., Earnest O., Erhirhie O. An investigation into the anti-diarrhoeal effects of aqueous and ethanol stem bark extracts of 
Alchornea cordifolia in wistar rats, J. of Pharmaco. and Phytochem. 2015; 4: 183-187.

17. Gatsing D., Nkeugouapi F.N., Nji-Nkah B. F., Kuiate J., Tchouanguep F. M. Antibacterial activity, bioavailability and acute toxicity evaluation of the leaf extract of Alchornea cordifolia (Euphorbiaceae), Int. J. of Pharm., 2010; 6: 173182.

18. Guo Z., Vangapandu S., Sindelar S.W., Walker L.A., Sindelar R.D.. Biologically active quassinoids and their chemistry: potential leads for drug design. Current Med. Chem.,2005; 12: 173-190.

19. Ishola I.O., Agbaje E.O., Akinleye M.O., Ibeh C.O., Adeyemi O.O. Antidepressant like effect of the hydroethanolic leaf extract of Alchornea cordifolia (Schumach. \& Thonn.) Mull. Arg. (Euphorbiaceae) in mice: involvement of monoaminergic system. J. Ethnopharm., 2014; 158: 364-372.

20. Ismaila O., Ishola R.B., Ashorobi, Olusegun A. Evaluation of the antinociceptive activities of the aqueous root extract of Alchornea cordifolia (Schumach and Thonn) Müll. Arg. (Euphorbiaceace), Int. J. of Appl Res. in Nat. Prod., 12012; 5: $37-42$

21. Jensen O., Nielsen A.O., Bjerregaard P., 1978. Pediculosis capitis treated with Quassia tincture. Acta Derm. Venereol., 58(6): 557-559.

22. Jude E. Okokon, Nkemnele Bensella Augustine \& Dinesh Mohanakrishnan. Antimalarial, antiplasmodial and analgesic activities of root extract of Alchornea laxiflora. Pharmaceutical Biology, 2017: 1-11.

23. Kamenan G., Kouakou-Siransy, Irié-Nguessan, Dally I., Kablan B.. Anxiolytic activity of an aqueous extract of Alchornea cordifolia (Euphorbiaceae) leaves. Afr J. of Pharm. and Pharmacology, 2013; 7: 816-821.

24. Kirby G.C., O’Neill M.J., Philippson J.D., Warhurst D.C. Invitro studies on the mode of action of quassinoids with activity against chloroqine-resistant Plasmodium falciparum. Biochem. Pharmacol., 1989; 38(24): 4367-4374.

25. Mambe F.T., Voukeng I. K., Beng V. P., and Kuete V. Antibacterial activities of methanol extracts from Alchornea cordifolia and four other Cameroonian plants against MDR phenotypes. J. of Taibah Univ. Medic. Sci., 2016: 1- 7.

26. Mavar-Manga H., Haddad L., Pieters C., Baccelli A., Penge J., Quetin-Leclercq. Anti-inflammatory compounds from leaves and root bark of Alchornea cordifolia (Schumach. \& Thonn.) M“ull. Arg. J. of Ethnopharm, 2008 115: 25-29.

27. Mbatchi S.F., Mbatchi B., Banzouzi J.T., Bansimba T., NsondeNtandou G.F., Ouamba J.M., Berry A., Benoit-Vical F. In vitro antiplasmodial activity of 18 plants used in Congo Brazzaville traditional medicine. Journal of Ethnopharmacology, 2006; 104(1-2): 168-174.

28. Mesia G.K., Tona G.L., Nanga T.H., Cimanga R.K., Apers S., Cos P., Maes L., Pieters L., Vlietinck A.J. Antiprotozoal and cytotoxic screening of 45 plant ex-tracts from Democratic Republic of Congo, J. of Ethnopharm., 2008; 115 : 409-415.

29. Mohammed R.K., Ibrahim S., Atawodi S.E., Eze E.D., Suleiman J.B. Anti-diabetic and Haematological Effects of nbutanol fraction of Alchornea cordifolia leaf extract in streptozotocin induced diabetic Wistar rats. Global J. of Medic. Plant Res., 2012; 1: 14-21.

30. Ngaha N.M., Dahlan I. and Massoma L.D. Alchornea Cordifolia, a special plant for traditional medicine: a review. Journal of Agroecology and Natural Resource Management, 2016; 3 (2): 140-144.

31. Noundou S. X., Krause R.W.M., Van Vuuren S.F., Tantoh N., Olivier D.K. Antibacterial effects of Alchornea cordifolia (Schumach. and Thonn.) Müll. Arg extracts and compounds on gastrointestinal, skin, respiratory and urinary tract pathogens. J. of Ethnopharm., 2016; 179:76-82.

32. Noundou S.X., Musyoka T. M., Moses V., Ndinteh D. T., Mnkandhla D., Hoppe H., ÖzlemTastan B. \& Krause R. M. Anti-HIV-1 integrase potency of methylgallate from Alchornea cordifolia using in vitro and in silico approaches. Scientific reports, 2019; 1-9.

33. Nsonde-Ntandou G.F., Banzouzi J.T, Mbatchi B, Elion-Itou RD, Etou-Ossibi AW, Ramos S, Benoit-Vical F, Abena AA and. Ouamba J.M. Analgesic and anti-inflammatory effects of Cassia siamea Lam. stem bark extracts. Journal of Ethnopharmacology 2010; 127: 108-111.

34. O.M.S. Promotion et développement de la médecine traditionnelle. Genève, séries de rapports techniques, 1978: $622 \mathrm{p}$.

35. Olaleye M. T., Kolawole A. O. and Ajele J. O. Antioxidant properties and glutathione s-transferases inhibitory activity of Alchornea cordifolia leaf extract in acetaminophen-induced liver injury. Iranian Journal of Pharmacology \& Therapeutics, 2007; 6: 63-66.

36. Toma W., Gracioso J.S., Andrade J.D.P., Hiruma-Lima C.A., Vilegas W., Souza Brito A.R.M. Antiulcerogenic activity of four extracts obtained from the bark wood of Quassia amara L. Biol. Pharm. Bull., 2002; 25(9):1151-1155.

37. Toma W., Gracioso J.S., Hiruma-Lima C.A., Andrade F.D.P., Vilegas W., Souza Brito A.R.M.. Evaluation of the analgesic and antiedematogenic activities of Quassia amara bark extract. J.Ethnopharmacol, 2003; 85: 19-23

38. Thomford A.K., et al. The ethanolic leaf extract of Alchornea cordifolia (Schum. \& Thonn.) Muell. Arg inhibits the development of dyslipidaemia and hyperglycaemia in dexamethasone-induced diabetic rats. J. App. Pharma. Sci., 2015; 5: 052-055.

39. Umukoro S., Aladeokin A.C. Evaluation of the Anti-Stress and Anticonvulsant Activities of Leaf Extract of Alchornea cordifolia in Mice. J. of Ethnopharm., 2010; 127: 768-770.

40. Wright C.W., O’Neill M.J., Philippson J.D., Warhurst D.C. Use of microdilution to assess in-vitro antiamoebic activities of Brucea javanica fruits, Simarouba amara stem, and a number of quassinoids. Antimicrob Agents Chemother. 1988; 32(11): 1725-1729.

41. Yinusa Raji, Ganiyat Kehinde Oloyede. Antiulcerogenic effects and possible mechanism of action of Quassia amara (Simaroubaceae) extract and its bioactive principles in rats. Afr. J. Tradit. Complement. Altern. Med., 2012; 9(1):112119.

42. Zimmermann M, 1983. Ethical guidelines for investigations of experimental pain in conscious animals. Pain, 1983; 16 : 109-110. 